\title{
THE GIUSTINIANI MEDICINE CHEST
}

\author{
by
}

\section{JOHN BURNETT*}

IN 1924, Henry Wellcome bought an Italian medicine chest through his agent in Rome. ${ }^{1}$ The chest was sold by a branch of the Giustiniani family living at Servallo, near Norcia. It was said to have been the sea medicine chest made in the middle of the sixteenth century for Vincenzo Giustiniani, the last Genoese ruler of the island of Chios, in the Aegean: my researches suggest that this is true. The chest is large - it takes two men to lift it - and in excellent condition for its age. Among the material which it contains are 126 bottles and pots for drugs, many with original labels, some with contents. It was an outstanding acquisition, and remains one of the most magnificent objects in the Wellcome collection.

\section{THE GIUSTINIANI}

From the thirteenth century until 1566, Chios was the richest island in the Aegean. Its wealth came chiefly from the mastic trade: the bush grew in profusion on the island, and the gum extracted from it had a ready market, particularly in Constantinople. In the mid-fourteenth century, some members of the Genoese branch of the Giustiniani family assumed control of Chios, acting as a trading company which organized the finance and defence of the island, leaving foreign affairs and criminal law in the hands of the mother government in Genoa. By 1560, the original family had expanded into something between a clan and a social class, since every shareholder in the company took the surname "Giustiniani". Thanks to the toleration of Suleiman the Magnificent, and to payment of a large annual tribute, they were allowed to remain wealthy.

Vincenzo Giustiniani (d. 1570) was the last Genoese podestà or governor of Chios. ${ }^{2}$ The Giustiniani maintained close links with French traders, and though his early years are obscure, Vincenzo certainly spent some time in France, and became a friend of Henri II. ${ }^{3}$ The Genoese government appointed him podestà of Chios at the

* John Burnett, M.A., M.Sc., Wellcome Museum of the History of Medicine, Science Museum, London SW7 2DD.

\footnotetext{
${ }^{1}$ The chest is now in the Wellcome Museum of the History of Medicine at the Science Museum, London. Inventory A641515.

2 Vincenzo Giustiniani, podestà of Chios, should be distinguished from his kinsman and contemporary, Cardinal Vincenzo Giustiniani (1519-82), Master General of the Dominican Order.

${ }^{3}$ Carl Hopf, Les Giustiniani, dynastes de Chios . . . traduite de l'allemand par Etienne A. Vlasto, Paris, Ernest Leroux, 1888, p. 151.
} 


\section{J. Burnett}

beginning of $1562,{ }^{4}$ and he ruled until the island was captured by the Turks in April 1566, when Piali Pasha, whose failure the previous year at the siege of Malta was thought to be partly due to Chian advice and Genoese support, ${ }^{5}$ took control of Chios by a ruse. Chios town was not sacked, and the Turks bought the property of the Genoese at nominal prices. Most of the Genoese were sent home: presumably the chest travelled with them.

After the fall of Chios, members of the wealthier Genoese families were first taken to Istanbul, which Vincenzo had already visited when delivering the annual tribute, and later to the former Genoese colony of Kaffa in the Crimea. In November 1567, the French ambassador interceded on behalf of the prisoners, and some of them were allowed to return to Chios or Genoa. ${ }^{6}$ Vincenzo Giustiniani travelled to Paris to seek employment at the court of Henri II's son, Charles IX. Charles - or more probably his mother, Catherine de' Medici - sent Giustiniani back to Istanbul in another role, ambassador to the Sublime Porte. It was a position of some importance, since until the Anglo-Turkish agreement of 1583, France was the official protector of all the Europeans in the lands under Turkish rule. In 1569, he was able to secure the release of the last Chian prisoners in Kaffa. ${ }^{7}$

\section{DESCRIPTION OF THE CHEST}

The chest is roughly cuboidal, with semicircular ends. It is $355 \mathrm{~mm}$. high, $455 \mathrm{~mm}$. deep, and $730 \mathrm{~mm}$. wide. The chest is made of wood, and covered with leather secured by round headed nails which show traces of gilding. The base is of carved wood finished with gold paint. The carving includes four eagles with outspread wings. At both ends of the chest, at half height, are gilt loop handles, each in the form of two dolphins holding in their mouths a cartouche, within which is a female head. These handles are almost identical to one in the Victoria and Albert Museum, which is also Italian and dates from the first half of the sixteenth century.

The lid of the chest is hinged, and is secured by a simple single-warded lock which is consistent with a date of 1560-70.8 There are three drawers in the body of the chest. The top one opens to the left and the lower two to the right.

On canvas fixed to the underside of the lid is an oil painting of a female figure riding in a chariot through a classical landscape. In her right hand she holds aloft a caduceus. The chariot is drawn by two large birds, possibly cranes. Although the style of the painting suggests that it dates from the seventeenth or eighteenth centuries - it is certainly not as old as the chest - a photograph taken when the chest first arrived in London shows that the painting was then in poor condition, particularly in the area of the chariot and birds. The painting seems to have been so heavily retouched in the

\footnotetext{
4 Philip Panteles Argenti, The occupation of Chios by the Genoese 1346-1566, 3 vols., Cambridge University Press, 1958, vol. 1, p. 362.

' Richard Hakluyt, The principal navigations voyages traffiques and discoveries of the English nation, 12 vols., Glasgow, James MacLehose, 1904-5, vol. 5, p. 112.

Hopf, op. cit., note 3 above, p. 85.

'Alexandros M. Blasto, A history of the island of Chios, London [privately printed], 1913, p. 60.

- Frank Alflatt, personal communication, 1980.
} 


\section{The Giustiniani medicine chest}

1920 s that it would be unwise to speculate about the iconography. 9

Beneath the lid are four large bowls with parchment covers, nine large rectangular bottles, and seven small triangular bottles, with compartments for five more. The whole of the interior of the chest is lined with red velvet.

On top of the lid is a small compartment containing an incomplete bullet holder of the kind illustrated by dalla Croce. ${ }^{10}$ The stem which unscrews into two parts is present, but only traces remain of the four flexible arms which would have clasped the bullet.

The top drawer holds fifty bottles, with compartments for another six, and four loose tops. The bottles have pewter caps which screw on to pewter mounts on top of the glass part of the bottles.

The second drawer has twelve open compartments, and ten more arranged in fives under two hinged lids. The undersides of the lids are painted in gold and red, showing foliage and an eagle with spread wings and a crown above its head.

The drawer contains a wooden box with painted decoration which holds scales and a pair of brass weights which appear to belong to a nested set. There is also a marble mortar with an agate pestle, two brushes, and two small pewter boxes. The following pieces of organic matter are also present, all presumably materia medica: three pieces of chalk, a slice of antler, a length of root, four fish ossicles, and three small pieces of fish bone.

The lowest drawer contains seventy-six pewter boxes. One compartment is empty. Almost all the boxes still have lids, and some still have handles on the lids.

The heraldic device which is crudely painted on the box in the middle drawer supplies evidence that a member of the Giustiniani family of Chios owned the chest. It shows a black eagle with a crown above its head, and below it a three-towered castle with all three towers of equal height. The whole is on a golden background. It is an adaptation of the arms of the Giustiniani of Chios as described by Crollalanza, ${ }^{11}$ and is distinct from those of the Giustiniani of Pesaro or Venice. Crollalanza says that the centre tower should be slightly higher than the flanking ones, but the Giustiniani themselves were not scrupulous on this point: many of the later Genoese coins of Chios (which were struck on the island), including those bearing the initials of Vincenzo Giustiniani, show all three towers the same height. ${ }^{12}$ The presence of the arms of Chios indicates a date of 1566 or earlier.

The chest is clearly a luxury object, being large and of fine craftsmanship. It is a prince's medicine chest. The selection of drugs, discussed below, suggests that it dates from the third quarter of the sixteenth century. It seems reasonable to say that it was

\footnotetext{
-I am indebted to Dr. Renate Burgess and William Schupbach of the Wellcome Institute for the History of Medicine for information and advice concerning the painting.

${ }^{10}$ Giovanni Andrea dalla Croce, Chirurgiae .. . libri septem, Venetiis, apud I. Zilettum, 1573, f. 134v.

11 "Di rosso, al castello d'argento sormonto da tre torri, quella di mezzo più elevata, aperto e fenestro del campo; col capo d'oro, all' aquila nascente di nero, coronata del campo." G.B. di Crollalanza, Dizionario storico-blasonico delle famiglie nobili e notabile italiane, 3 vols., Pisa, Presso la Direzione del Giornale Araldico, 1886-90, vol. 1, p. 488.

12 Gustave Schlumberger, Numismatique de l'orient latin, Paris, Ernest Leroux, 1875, pp. 430-431 and plate XV.
} 


\section{J. Burnett}

either made for podestà Vincenzo, or for one of his immediate predecessors. Indeed, there appear to be no grounds for disbelieving the tradition that it was made for Vincenzo Giustiniani, podestà of Chios, at some time between 1562 and 1566.

\section{THE DRUGS IN THE CHEST}

Ninety-five of the drug containers carry paper labels with legible or partly legible names on them. These names are listed below, in an appendix.

Of the thirty-nine items of materia medica which can be identified, twenty-seven are given by Dioscorides, thirty-four by Mattioli, and twenty-one by the 1567 Ricettario Fiorentino. Three are not on any of these lists (mechiocam, crocus metallorum, and unicorn's horn).

The influence of Dioscorides on sixteenth-century materia medica had increased rapidly after the publication of the translations of his Herbal by Jean Ruel at Paris and Ermolao Barbaro at Venice, both in $1516 . .^{13}$ By the middle of the century, Dioscorides' influence was at its height, so it is hardly surprising that two-thirds of the identifiable drugs in the chest are found in the Herbal. Several more of the drugs in the chest were introduced by Arabic writers. The most interesting groups are those drugs from the New World, and those which may show the influence of Paracelsus.

It is to be expected that American drugs would be found in a Genoese medicine chest, since the Genoese were the economic power behind the Spanish exploitation of the New World; indeed, it is known that the Giustiniani were represented in Seville, the centre for the transatlantic trade. ${ }^{14}$ The American drugs in the chest are guaiacum and mechiocam, and probably some of the tree balms. ${ }^{15}$ Guaiacum probably arrived in Europe as early as 1508, although it did not become widely used until the Fuggers began to stimulate the trade in it in 1518. The introduction of mechiocam was later and slower. We should have expected that other American drugs would have been present if the chest had been made slightly later, such as jalap, which came into vogue around the middle of the century, and sarsaparilla, imported in quantity from $1568 .{ }^{16}$ Given the limited number of American drugs, it may be significant that the chest dates from the same decade that saw the publication of the two books which gave Europe a good knowledge of foreign materia medica: Garcia d'Orta's Coloquios dos simples, $e$ drogas he cousas mediçinais da India (1563) and Nicolas Monardes' Dos libros... de todas las cosas que traen de nuestras Indias Occidentales (1569-71).

\footnotetext{
13 Jerry Stannard, 'Dioscorides and renaissance materia medica', in Marcel Florkin (editor), Materia medica in the XVIth century: Proceedings of a symposium of the International Academy of the History of Medicine held at the University of Basel 7th September 1964, (Analecta Medico-Historica, 1), Oxford, Pergamon Press, 1966, pp. 1-21; Karen Meier Reeds, 'Renaissance humanism and botany', Ann. Sci., 1976, 33: 519-542; and John M. Riddle, 'Dioscorides', in F. E. Cranz (editor), Catalogus translationum et commentariorum, Washington, The Catholic University of America Press, 1980, Vol. 4, pp. 1-143.

14 Ruth Pike, 'The Genoese in Seville and the opening of the New World', J. econ. Hist., 1962, 22: 348-378.

is The 1567 Ricettario Fiorentino defines balsamo liquore as "Balsamo d'Indie occidentali, ò olio di Noci moscade lambiccato, ò olio di Gherofani." (p. 114).

${ }^{16}$ Francisco Guerra, 'Drugs from the Indies and the political economy of the sixteenth century', in Florkin (editor), op. cit., note 13 above, pp. 29-54. Decotto di salsapariglia is, however, given in the 1567 Ricettario Fiorentino (p. 126).
} 


\section{The Giustiniani medicine chest}

It is impossible to say whether any individual drug in the chest is due to Paracelsus, or whether it has been derived from the mass of popular remedies on which he also drew. However, it is perhaps worthy of note that Paracelsus was particularly enthusiastic about magesteries of coral, and was the first to describe crocus metallorum. ${ }^{17}$ Crocus metallorum is not mentioned in any of the contemporary pharmacopoeiae, but Paracelsian texts began to be printed in quantity in Germany in the $1560 \mathrm{~s},{ }^{18}$ so it was fairly widely known at the time the chest was stocked. It could not be argued, however, that Paracelsian ideas influenced the overall selection of drugs in the chest, since it includes polypharmaceutical preparations and guaiacum - which Paracelsus reviled.

Distillation was probably fairly common in the fifteenth century, and the distillation of medicines became widespread after the publication of Brunschwygk's two books in 1500 and $1512 .{ }^{19}$ The ten acque in the chest are certainly distilled waters: this is the use of acqua in the Ricettario Fiorentino, ${ }^{20}$ and of aqua in the Augsburg Enchiridion. ${ }^{21}$ Elixir vitae was also distilled, and flowers of sulphur had been prepared by sublimation since the Middle Ages. There is only one drug in the chest described as a quintessence, Quinta essentia di rosmarin, and it is interesting that this is one of the few distilled waters mentioned in the Cologne Dispensarium. ${ }^{22}$ The seven estratti may also have been distilled, but are more likely to be the products of simple boiling.

\section{THE SEA MEDICINE CHEST}

It has been said that the Giustiniani chest is the oldest surviving sea medicine chest: $^{23}$ this is probably true, but it is not a typical sea medicine chest. Chests for treating ships' crews from the sixteenth to the nineteenth century were normally large often as large as the Giustiniani chest - and held substantial quantities of a limited number of drugs. In earlier centuries, the drugs were mostly for external application. Since it was normally used by a barber-surgeon or surgeon, the chest also contained instruments, particularly knives and razors, and other equipment such as combs for removing lice. This is borne out by the one piece of near-contemporary evidence which we have, the contents of the ship's medicine chest from the Mary Rose, which sank in Portsmouth harbour in 1545: it was clearly very different from the Giustiniani one. ${ }^{24}$

Although diseases specific to life at sea were becoming recognized in the sixteenth century, it is unlikely that they would have been a problem in the eastern

\footnotetext{
${ }^{17}$ Klaus Bosch, 'Zur Vorgeschichte chemiatrischer Pharmakopöepräparate im 16./17. Jahrhundert', Veröffentlichen aus dem Pharmaziegeschichtlichen Seminar der Technischen Universität Braunschweig, 1980, 21: 1-224, especially pp. 112-113.

18 Allen G. Debus, 'The pharmaceutical revolution of the renaissance', Clio Medica, 1976, 11: 307-317.

19 Robert James Forbes, Short history of the art of distillation, Leiden, E. J. Brill, 1948, p. 109.

${ }^{20}$ Ricettario Fiorentino, Florence, 1567, pp. 208-209.

${ }^{21}$ Enchiridion, sive ut vulgo vocant dispensatorium, compositorum medicamentorum pro Reipub, Augstburgensis pharmacopoeis, Augsburg, 1564, coll. 194-196.

${ }_{22}$ Dispensarium usuale pro pharmacopoeis inclytae reipub. Colonien, Coloniae, apud heredes Arnoldi Brickmani, 1565, f. $24^{\mathrm{v}}-25^{\mathrm{v}}$.

${ }^{23}$ Irmgard Müller, 'Entwicklung der Schiffspharmazie', Dt. ApothZtg, 1970, 110: 1241-1249.

24 Surgeon Vice-Admiral Sir James Watt, personal communication, 1981.
} 


\section{J. Burnett}

Mediterranean, since they were chiefly the result of dietary deficiencies on long voyages. One would expect a medicine chest for an entire ship's complement to hold large stocks of ointments for treating wounds, since piracy and Ottoman harassment were common in the Aegean. Instead, there are small amounts of a wide range of internal medicines, including a drug for preventing miscarriages. Several of the drugs, particularly mithridatium, orvietanum, theriac, unicorn's horn, terra sigillata, and the preparation of bezoar stone, were very expensive and would certainly not have been used to treat the ordinary members of a ship's crew.

Could the chest have been used by a physician in the palace of Chios? This seems unlikely. A large household would probably have had its own set of earthenware drug jars, as, for example, did the Chigi family in Rome later in the sixteenth century. ${ }^{25}$

There remains the possibility that, rather than being part of the palace furnishings, the chest was taken on board ship by Vincenzo Giustiniani. We know that he travelled to Istanbul to pay the Turks the annual tribute, a journey of some three hundred miles in each direction.

Chios owned both round ships and galleys. The five or six round ships which were in the island's possession around 1560 were probably caravels of some 120 tons, slow cargo vessels. ${ }^{26}$ They were not the kind of ship in which the podesta would travel. After 1530, the larger galleys had lost their commercial role and were purely fighting ships. ${ }^{27}$ Their accommodation was limited. The stern held only three cabins: the top one for the navigator and steersman, the lowest for storage, whilst the centre cabin was shared by the captain, officers, and any distinguished passengers. ${ }^{28}$ However, there would almost certainly have been room for a medicine chest, since although the chest is large in comparison with other medicine chests, its dimensions are relatively modest when compared with those of a cabin in a galley.

\section{CONCLUSIONS}

The Giustiniani chest is not a sea medicine chest in the sense that the other examples described by Müller are sea medicine chests. However, it was almost certainly made for use by a wealthy man on sea journeys. Such internal evidence as there is bears out the Giustiniani family tradition that the chest was the property of Vincenzo Giustiniani, podestà of Chios from 1562 to 1566.

\section{APPENDIX: A LIST OF DRUGS IN THE GIUSTINIANI CHEST}

I have given below a list of the ninety-five labels which are legible in whole or in part. References are given to Berendes' edition of the Herbal of Dioscorides (Diosc.), ${ }^{29}$ to Mattioli's commentary on Dioscorides (1554) which includes material of Arabic

\footnotetext{
${ }^{25}$ Guiseppi Carbonelli, 'The private pharmacy of Pope Alexander VII', Chem. Drugg., 1929, 110: 805-806. The pharmacy was set up by the ancestors of Alexander VII (1599-1667).

2 Hakluyt, op. cit., note 5 above, vol. 5, p. 113.

${ }^{27}$ Frederic Chapman Lane, Venetian ships and shipbuilders of the renaissance, Baltimore, Md., Johns Hopkins Press, 1934, p. 31.

20 Ibid., p. 18.

20 Dioscorides, Arzneimittellehre in fünf Buchern, translated and edited by Julius Berendes, Stuttgart, Ferdinand Enke, 1902.
} 


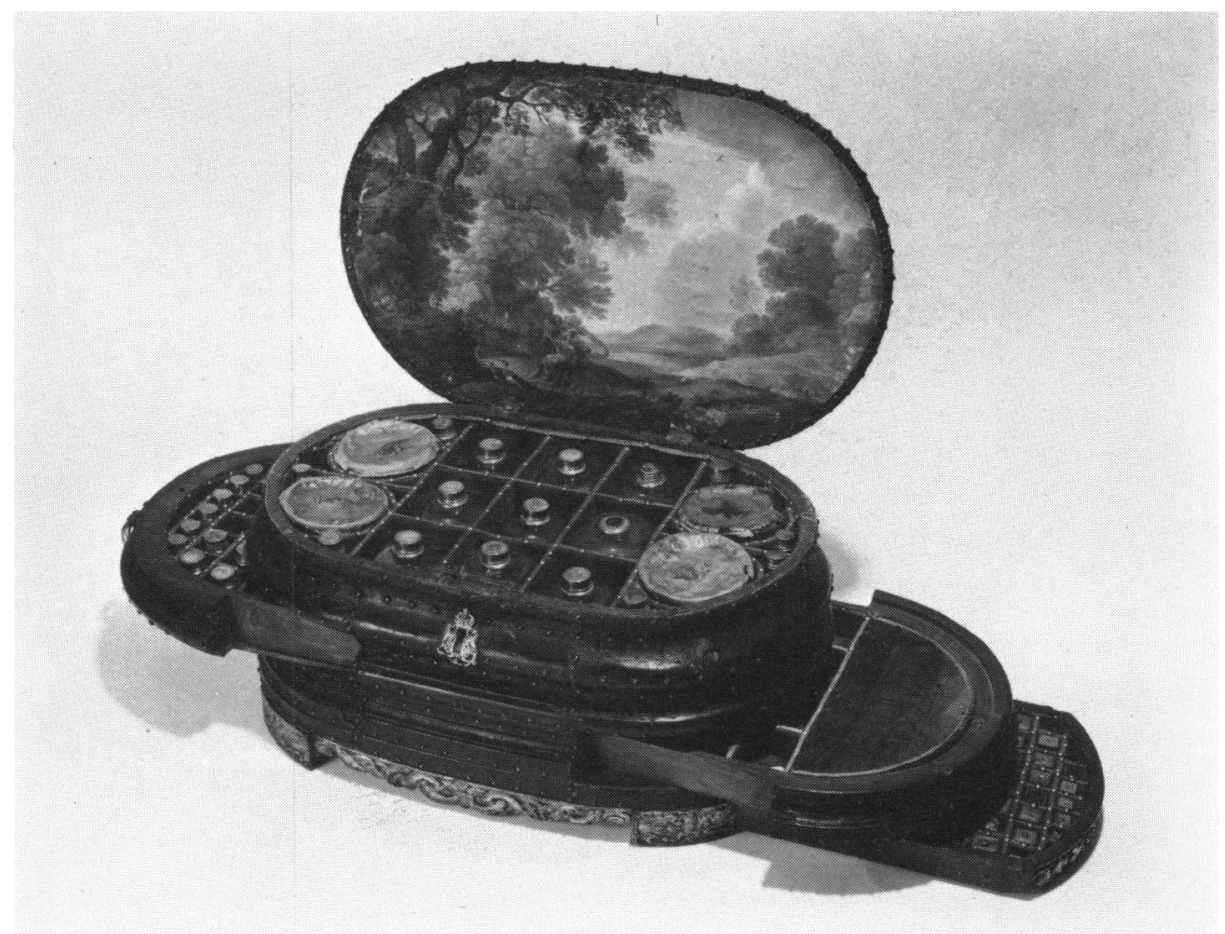

Figure 1. The Giustiniani medicine chest, c. 1565 (Science Museum copyright).

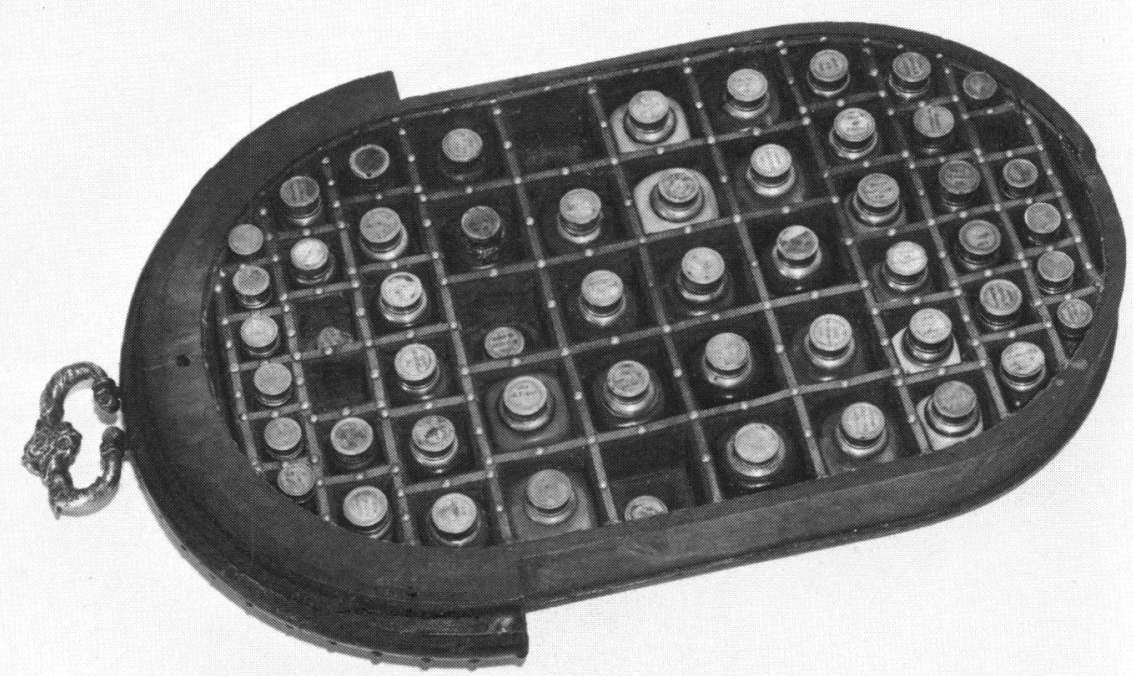

Figure 2. The top drawer of the chest, containing bottles of different sizes (Science Museum copyright). 




Figure 3. The bottom and middle drawers of the chest. The lower drawer contains pewter boxes, the middle one, materia medica and a mortar and pestle. On the left is a box with the arms of Chios painted on it (Science Museum copyright).

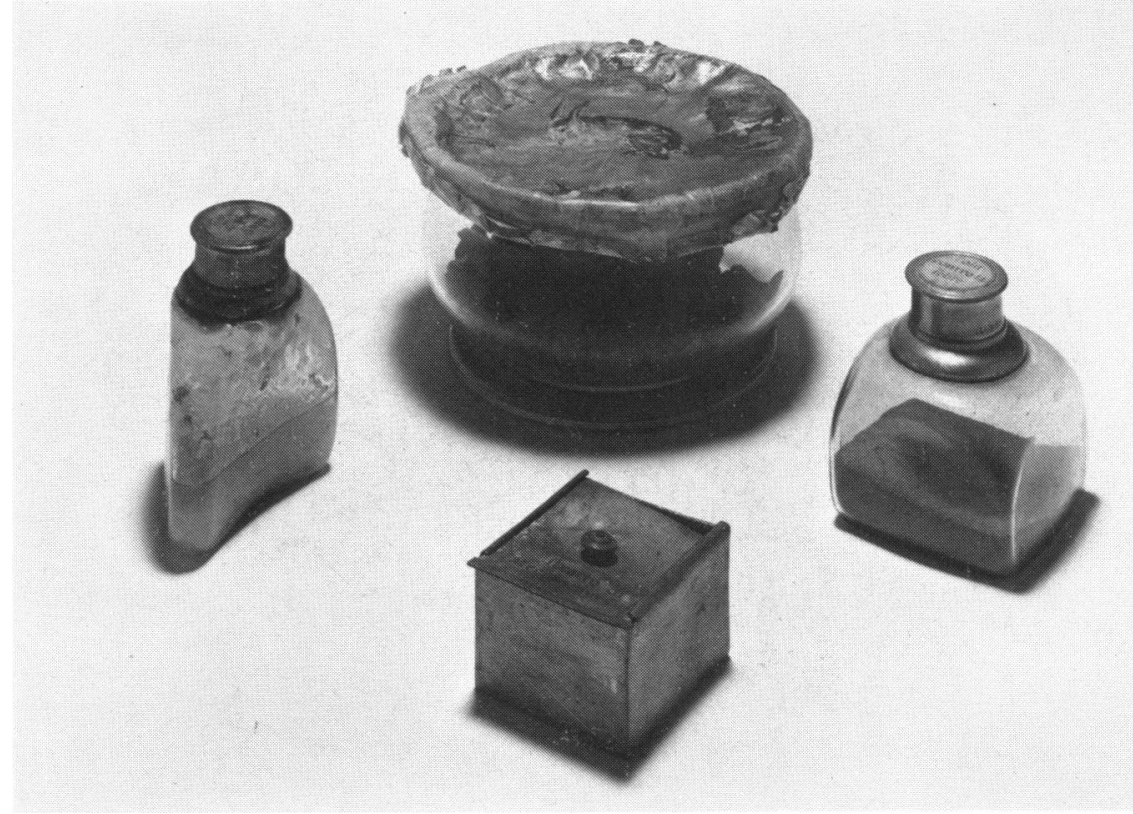

Figure 4. Four drug containers from the chest: bottles for Olio di cento anni and Polu: contro la febre, a pewter box for Estratto di Mechiocam, and a glass bowl with a parchment cover on which is painted a rabbit or hare (Science Museum copyright). 


\section{The Giustiniani medicine chest}

origin (Matt.), ${ }^{30}$ and to the 1567 edition of the Florentine pharmacopoeia, the Ricettario Fiorentino (RF). ${ }^{31}$ A reference is cited if either the compound or its named chief constituent is given in these printed lists, even if the preparation described is different. An asterisk indicates that part of the original contents survives.

The labels themselves appear to have been written in a sixteenth-century hand. The names of the drugs are in black ink, and the numerals which accompany them (each container is numbered) in red. There is a separate sequence of numbers for the bottles in the top of the chest, for those in the middle drawer of the chest, and for the containers in the lowest drawer of the chest.

IN THE TOP OF THE CHEST

5. Acqua di Cannella Aromatic water of cinnamon. Diosc. I. 13, Mat+ 1, RF 154.

6. Acqua di Scorzonero Aromatic water of black salsify. Diosc. III. 66, Matt. 361.

7. Acqua di Scordio vero Aromatic water of water germander. Diosc. III. 114, Matt. 397, RF 141.

8. Acqua d'Anisi Aromatic water of anise. Diosc. III. 58, Matt. 355, RF 156.

9. Acqua di Cardo santo Aromatic water of the holy thistle. Matt. 385.

10. Acqua d'Anime di Persiche Aromatic water of the stone of the walnut. Diosc. I. 178, Matt. 146, RF 202.

11. Acqua di brodio di Ginapro Aromatic water of an unidentified part of the juniper bush. Diosc. I. 103, Matt. 81.

12. Acqua di Ruta Capraria Aromatic water of rue. Diosc. III. 45, Matt. 348.

14. Olio di cento anni* Hundred year oil.

15. Olio di $\left[\ldots J^{*}\right.$ Unidentified oil.

IN THE MIDDLE DRAWER OF THE CHEST

1. Mag. di coralli rossi Magestry of red coral. Coral is given at Diosc. V. 138, Matt. 626, RF 201.

4. Olio da vermi* Oil for worms.

6. Mag. di coralli bianchi* Magestry of white coral. See 1.

7. Polu: contro il delirio* Powder for delirium.

8. Balzamo artifitiato* Unidentified balm.

9. Olio contro le ferite* Oil for wounds.

10. Elixir uitae* Elixir of life. Probably the distilled preparation based on cinnamon, ginger, and wine given as Aqua vitae in the Augsburg Enchiridion, ${ }^{32}$ and not simply brandy. The Cologne Dispensarium gives a distilled drug called Elixir, sive aqua vitae, containing seventy-seven ingredients. ${ }^{33}$

11. Quinta essentia di Rosmarin:* Quintessence of rosemary. Diosc. III. 72, Matt. 370.

13. Acqua d'Echio Viperario Aromatic water of viper's bugloss. Diosc. IV. 27, Matt. 448.

13. Polu: da Caroli* Powder of camomile. Diosc. III. 144, Matt. 317, RF 210. A green powder.

14. Polu: da Caroli* Powder of camomile. See above. A brown powder.

30 Pietro Andrea Mattioli, Commentarii in libros sex Pedacii Dioscoridis, Venetiis, in officina Erasmiana, apud Vincentum Valgrisium, 1554.

${ }^{31}$ Ricettario Fiorentino, Florence, 1567.

32 Enchiridion ..., coll. 195-196.

${ }^{33}$ Dispensarium . . , f. 118. 


\section{J. Burnett}

15. Polu: del Cornaechino* Pulvis cornaechinus, based on scammony, cream of tartar and diaphoretic antimony.

17. Fior di Zolfo* Flowers of sulphur. Diosc. V. 123, Matt. 618, RF 86.

18. [...]da Denti* Unidentified drug for teeth.

19. Sale d'Assinthio* Salt of absinthe. Diosc. III. 26, Matt. 328, RF 123.

20. Sale di scorzo nero* Salt of black salsify. See bottle 6 in top of chest.

22. Polu: contro la febre* powder against the fever.

23. Cremor di rabarbo cristallin: * Cream of crystallized rhubarb. Diosc. III. 2, Matt. 309, RF 186.

24. Pietra contro il calculo* Stone for urinary calculi. Perhaps adamas, which has sometimes been identified with diamond. ${ }^{34}$

2. . . Olio d' Ammi* Oil of bishop's-weed. Diosc. III. 63, Matt. 358. RF 154.

31. [...] triacale p. infusion:* Preparation of theriac for infusion. Theriac is given at Matt. 693, RF 170.

32. Tintura di $\left[. . . J a i o^{*}\right.$ Unidentified tincture.

34. Olio della Spagnolas* Spanish oil.

35. Olio della Spagnola* Spanish oil.

38. Olio di Piane* Plane-tree oil. Diosc. I. 107, Matt. 86.

39. Balzamo da ferite* Balm for wounds.

40. Conf. [...]d [... Jci* Unidentified confection.

42. Liquore da flussi* Liquour for dysentery.

43. Antimonio Stibnite, i.e. native antimony trisulphide. Diosc. V. 99, Matt. 596, RF 83.

44. Olio di Senape* Oil of mustard. Diosc. II. 183, Matt. 279, RF 96.

45. Acqua triacale Bezuartica Aromatic water of theriac and bezoar stone. Bezoar is given at Matt. 609.

46. Olio di Carabe* Oil of amber. Matt. 88, RF 202.

48. Olio di scorzo di cedro Oil of the bark of the cedar. Diosc. I. 105, Matt. 83, RF 118.

49. Olio viperino* Viper oil. Diosc. II. 19, Matt. 169, RF 193.

50. Olio di lina still:* Distilled oil of elatine. Diosc. IV. 40, Matt. 521.

... Tintura di crifollo Unidentified tincture.

\section{IN THE LOWEST DRAWER OF THE CHEST}

4. Polure con. la febre Powder against the fever.

9. Sal di coralli bianchi Salt of white coral. See middle drawer, bottle 1 .

14. Crocus metall:* Crocus metallorum, the impure oxysulphide of antimony, prepared by calcination.

16. Oro purg:* Purgative gold. The box contains gold leaf which would, according to Arabic practice, have been the basis of a purgative preparation. Matt. 606.

19. Polv. per le morici Powder for piles.

20. Estratto di grani di Sambuco* Extract of sambucus seeds. Diosc. IV. 171, Matt. 548, RF 211.

21. [. . .] di coralli rossi Preparation of red coral. See middle drawer, bottle 1.

21. [Estr]atto di [poli]podio* Extract of polipody. Diosc. IV. 184, Matt. 557, RF 140, 169.

22. Estratto [... Unidentified extract.

23. Estratto di ligno santo* Extract of holy wood, i.e., guaiacum. Matt. 107, RF 125.

23. Sulphur metall: Metallic sulphur. Diosc. V. 123, Matt. 618, RF 86.

24. Estratto di Sena* Extract of senna. Matt. 368, RF 125.

\footnotetext{
${ }^{34}$ Eucharius Rösslin, On minerals and mineral products: chapters on minerals from his "Kreutterbuch", translated and edited by Johanna Schwind Belkin and Earle Radcliffe Caley (Ars medica, Abt. 4, Landessprachige und mittelalterliche Medizin, Bd. 1), Berlin, Walter de Gruyter, 1978, pp. 55, 211.
} 


\section{The Giustiniani medicine chest}

25. Estratto di Elleboro* Extract of hellebore. Diosc. IV. 149, Matt. 526.

27. Estratto d'Agarico* Extract of agaric. Diosc. III. 1, Matt. 306, RF 186, 195.

29. Es/tra]tto [....* Unidentified extract.

2 ... Estratto di Rabarbaro* Extract of rhubarb. See middle drawer, bottle 23.

30. Estratto di Mechiocam* Extract of mechiocam.

31. Orvietano Orvietanum.

32. Vnguento da gambe* Ointment for legs.

33. Ceroto pro foetus retentione* Plaster for retaining the foetus, i.e., for preventing miscarriages.

34. Vnguento da milza* Ointment for the spleen. RF 229.

35. Ung. da fuoco de Capua* Capuan ointment da fuoco (lit. from fire): probably indicates that fire was used in preparing the ointment. RF 220 gives four unguenti da fuoco magistrale, all with completely different constituents.

36. Mitridato* Mithridatium. RF 172.

37. Vnguento gratia dei Ointment gratia dei. RF 241.

38. Ceroto da ferite* Plaster for wounds.

39. Ceroto da stommaco* Plaster for the stomach. RF 219 gives Unguento da stommaco.

41. Teriaca nuoua* New theriac.

42. Teriaca vecchia* Old theriac.

43. Vnguento da morici* Ointment for piles.

44. Cerotto speronaglia* Unidentified plaster.

46. Pillole d'Aloe* Pills of aloes. Diosc. III. 22, Matt. 327, RF 87.

47. Vnguento da caroli* Camomile ointment. See middle drawer, bottle 13.

48. Triaca d'Andromaco* Theriac of Andromachus. Matt. 693, RF 170.

49. Bolo Armeno Orientale* Armenian earth. Matt. 609, RF 191.

50. [...]d[...]Monfioail... /* Unidentified.

52. Giacinto* Hyacinth, probably the plant rather than the semi-precious stone. Diosc. IV. 63, Matt. 468.

54. Elettuario [...* Unidentified electuary.

55. Elettuario per $i$ denti* Electuary for the teeth.

57. Terra sigillata RF 201, cf terra lemnia at Diosc. V. 113, Matt. 607.

60. Corno di ceruio prep. * Preparation of the horn of the stag. Diosc. II. 43, Matt. 193, RF 207.

61. Corno di ceruio prep ${ }^{t o}$ Preparation of the horn of the stag. See 60.

63. Pol vere[.... Unidentified powder.

67. Polure da [.... Je Vaioli Powder of ... and violet. Violet is given in Diosc. IV. 120, Matt. 511, RF 122.

69. Corno di ceruio prep ${ }^{t o *}$ Preparation of the horn of the stag. See 60.

... Polv. p. le morici Powder for piles.

... T $T$. ..] Probably a form of theriac. There were two words on the label.

... Giacinto* Hyacinth. See 52.

... Ung. di fuoco [sic/*. See 35.

... Corno d'Vnicorno* Horn of the unicorn.

\section{ACKNOWLEDGEMENTS}

I would like to thank R. J. Driscoll and Dr. V. Nutton for their help in identifying the drugs, and Dr. B. Bracegirdle and Dr. J. V. Field for their helpful comments on a draft of this note. The photographs were taken by Adrian Clarke. 